\title{
PERSEPSI KONSUMEN TERHADAP BAURAN PROMOSI (PROMOTIONAL MIX) PADA MATAHARI DEPARTMENT STORE BENGKULU
}

\author{
Seprianti Eka Putri \\ Program Studi Manajemen Fakultas Ekonomi Universitas Bengkulu
}

\begin{abstract}
The objective of this research is to know the consumers' perception toward promotional mix at Matahari Departement Store Bengkulu. This research represents of survey which representing problem in the form of fact in this time from a certain phenomenon. The data was used primary data through distribution of questionnaire. The respondents in this research are consumers' of Matahari Departement Store equal to 100 respondents. The sample taken was accidental sampling. The data analysis was used descriptive with frequency distribution, means, and percentages. Pursuant to result of data analysis obtained result of that the consumers' perception toward promotional mix at Matahari Departement Store have an a good level.
\end{abstract}

Key Words: Advertising, Sales Promotion, Personal Selling, Direct Marketing, Publicity and Customers' perception

\section{PENDAHULUAN}

\section{Latar Belakang}

Masyarakat Bengkulu sekarang ini mulai memasuki era gaya hidup kritis, kreatif, dan inovatif terhadap sesuatu yang baru dan modern sesuai dengan trend. Kenyataan ini juga berlaku pada aktivitas kehidupan sehari-hari, khususnya dalam hal memilih dan membeli suatu produk.

Dengan adanya beberapa beberapa mall, department store, dan pasar swalayan (supermarket) yang lokasinya relatif berdekatan, dengan sendirinya akan melahirkan persaingan yang ketat untuk merebut pengunjung dan pembeli. Selain itu persaingan juga datang dari beberapa pedagang eceran di pasar-pasar tradisional dan toko-toko yang tersebar pada wilayah yang sama.

Saat ini bisnis retailing di Bengkulu dari waktu ke waktu semakin diminati oleh seluruh lapisan masyarakat. Mereka cenderung menggabungkan kegiatan pemasaran dan konsumen dalam berbelanja, dengan berbagai kegiatan lainnya seperti rekreasi atau sekedar jalan-jalan. Fenomena ini setidaknya mendorong pemasar untuk meraih dan menggunakan kesempatan tersebut guna memasarkan produk dalam kerangka pencapaian sasaran dan tujuan perusahaan.

Keberhasilan perusahaan dalam memasarkan produknya sangat ditentukan oleh ketepatan strategi yang dipakai, yang disesuaikan dengan situasi dan kondisi dari sasaran pasar. Dalam menentukan strategi pemasaran pada sasaran pasar yang tepat, pihak pemasar perlu mengkaji setiap karakteristik perilaku konsumen, yang diimplementasikan ke dalam harapan dan keinginannya.

Dengan mengetahui alasan yang mendasari mengapa konsumen melakukan pembelian, maka dapat diketahui strategi yang tepat untuk digunakan. Dengan kata lain, pihak pemasar harus mengaktualisasikan setiap harapan konsumen menjadi 
suatu kepuasan atas pelayanan yang diberikan. Di mana hal tersebut merupakan kunci keberhasilan yang menjadikannya berbeda dari pesaingnya. Karena jika tidak demikian maka perusahaan akan ditinggalkan oleh pelanggannya, seperti pendapat yang dikemukakan dibawah ini:

Semakin disadari bahwa pelanggan merupakan aset bagi perusahaan. Dengan pemasaran yang semakin ketat, tanpa memiliki pelanggan tetap, perusahaan dengan mudah mengalami resiko kemunduran dalam bisnisnya. Bahkan lebih ekstrim lagi perusahaan akan mengalami kerugian yang cukup besar dan ditinggalkan pelanggan (Keegan, 2002).

Perhatian terhadap peningkatan kualitas pelayanan dari waktu ke waktu menjadi semakin penting. Seiring dengan perkembangannya, masyarakat sebagai konsumen tidak lagi bertindak sebagai objek dalam penilaian terhadap kualitas pelayanan, melainkan telah menjadi salah satu subjek penentu dalam menilai akan kualitas pelayanan suatu perusahaan, seperti pandangan yang dikemukakan Bitner (1992) bahwa : “....banyak penelitian menyatakan, kepuasan pelanggan sering ditentukan oleh kualitas produk atau jasa yang ditawarkan. Dalam konteks jasa, beberapa kepuasan pelanggan digambarkan sebagai suatu antesenden dari kualitas jasa....".

Berkaitan dengan hal di atas, pemasaran tidak hanya sekedar membicarakan produk, harga produk, mendistribusikan produk, tetapi juga mengkomunikasikan produk tersebut kepada masyarakat agar produk itu dikenal dan pada akhirnya dibeli oleh konsumen. Untuk memperkenalkan produknya, maka suatu usaha perlu melakukan promosi kepada para calon konsumennya agar dapat mengambil keputusan untuk membeli produk yang ditawarkan.

Promosi merupakan salah satu faktor penentu keberhasilan suatu program pemasaran. Dalam persaingan yang semakin ketat, perusahaan tidak hanya dapat mengandalkan peningkatan mutu dan pengembangan produk jasa semata, walaupun berkualitasnya suatu produk, bila konsumen belum pernah mengetahuinya dan tidak yakin kalau produk tersebut akan berguna bagi mereka, maka mereka tidak akan pernah membelinya. Produk yang dihasilkan oleh perusahaan agar dapat dikenal dengan baik dan akhirnya dibeli oleh konsumen, maka perusahaan perlu melakukan kegiatan promosi, yang terdiri dari periklanan, promosi penjualan, personal selling, publisitas dan pemasaran langsung.

Menurut Sunarto (2006) menyatakan bahwa promosi yang menarik dapat membuat konsumen membeli produk atau jasa yang ditawarkan kepada mereka. Tjiptono (2004) menyatakan bahwa promosi adalah suatu aktivitas pemasaran yang berusaha menyebarkan informasi, mempengaruhi/ membujuk, dan/atau mengingatkan pasar sasaran atas perusahaan dan produknya agar bersedia menerima, membeli, dan loyal pada produk yang ditawarkan perusahaan yang bersangkutan.

Matahari Departement Store Bengkulu adalah salah satu perusahaan retail besar di Indonesia dan baru-baru ini melakukan ekspansi usaha di Bengkulu. Matahari Departerment Store Bengkulu mulai beroperasi sekitar satu tahun yang lalu dan berada pada kompleks area Bengkulu Indah Mall (BIM) yang beralamat di kawasan wisata Pantai Panjang Bengkulu. Matahari Departement Store adalah swalayan yang bergerak dalam retail pakaian dan accecories

$$
\text { Management Insight, } \mathcal{9}(1): 45-54
$$


Sebagai perusahaan yang baru memulai usaha di Bengkulu, tentu saja saat ini Matahari Departement Store Bengkulu tengah giat-giatnya melakukan kegiatan promosi. Tujuannya tidak lain adalah memperoleh pelanggan sebanyak mungkin dengan berbagai daya tarik dan layanan yang diberikan. Apalagi di kompleks area BIM tersebut telah ada Hypermart yang lebih dahulu beroperasi sejak 3 (tiga) tahun yang lalu.

Berkaitan dengan hal di atas, peneliti tertarik untuk melakukan penelitian berkaitan dengan kegiatan bauran promosi (promotional mix) yang dilakukan oleh manajemen Matahari Departement Store Bengkulu dalam memasarkan produkproduknya, sehingga permasalahan yang akan dibahas dalam penelitian ini adalah "Bagaimana persepsi konsumen terhadap bauran promosi (promotional mix) pada Matahari Departement Store Bengkulu?"

\section{TINJAUAN PUSTAKA}

\section{Bauran Promosi (Promotional Mix)}

Promosi adalah sebuah upaya dari pemasar (marketer) dalam menginformasikan dan mempengaruhi orang atau pihak lain untuk tertarik melakukan transaksi atau untuk melakukan pertukaran produk barang atau jasa yang dipasarkannya Kombinasi spesifik dari metode-metode promosi yang digunakan untuk sebuah produk atau family product disebut dengan promotin mix (bauran promosi). Kotler (2001) menyatakan bahwa bauran promosi adalah tatanan alat-alat pemasaran yang digunakan perusahaan untuk mencapai tujuan pemasarannya di dalam pasar sasaran.

Lebih lanjut Kotler (2001: 264-312), menyatakan bahwa unsur bauran promosi (promotion mix) terdiri atas lima perangkat utama, yaitu :

1. Periklanan (Advertising)

Kotler (2001) menyatakan bahwa periklanan adalah egala bentuk kehadiran dan promosi dari ide barang atau jasa yang nonpersonal oleh pihak tertentu. Sedangkan Madura (2001) menyatakan bahwa periklanan adalah penyajian penjualan non personal yang dikomunikasikan melalui bentuk media atau non media untuk mempengaruhi sejumlah besar konsumen.

Sementara itu, Swastha (2002) menyatakan bahwa periklanan adalah komunikasi non-individu dengan sejumlah biaya, melalui berbagai media yang dilakukan oleh perusahaan, lembaga non-laba serta individu-individu. Sunarto (2004) menyatakan periklanan sebagai biaya yang harus dikeluarkan sponsor untuk persentasi dan promosi non-pribadi dalam bentuk gagasan, barang atau jasa.

Dari uraian di atas, disimpulkan bahwa iklan adalah alat utama bagi perusahaan untuk mempengaruhi konsumennya. Iklan dapat dilakukan oleh perusahaan lewat surat kabar, radio, majalah, bioskop, televisi, ataupun dalam bentuk poster-poster yang di pasang di pinggir jalan atau tempat-tempat yang strategis (Swastha, 2002).

Menurut Kotler (2001), ada beberapa ciri yang membedakan periklanan dengan bauran promosi yang lain yaitu:

a. Public presentation, kehadiran periklanan pada publik menghasilkan semacam legitimasi atas produk.

$$
\text { Management Insight, } 9 \text { (i):45 54 }
$$


b. Pervasiveness, periklanan memungkinkan produsen menampilkan produknya secara berulang-ulang agar makna pesannya dapat diserap dengan baik oleh khalayak luas.

c. Produk lebih ekspresif, dengan periklanan profil produk dan perusahaan dapat ditampilkan secara lebih dramatis.

d. Impersonality, periklanan adalah alat komunikasi yang impersonal, merupakan alat komunikasi satu arah dan pemirsanya tidak memiliki obligasi apa-apa untuk memperhatikannya, mengikutinya atau tidak.

2. Promosi Penjualan (Sales Promotion)

Tjiptono (2004) menyatakan bahwa promosi penjualan adalah bentuk persuasi langsung melalui penggunaan berbagai insetif yang dapat diatur untuk merangsang pembelian produk dengan segera dan/atau meningkatkan jumlah barang yang dibeli pelanggan. Sementara itu, Sunarto (2004) menyatakan bahwa promosi penjualan adalah insentif jangka pendek untuk mendorong pembelian atau penjualan suatu produk atau jasa. Brannan (2004) menyatakan bahwa promosi penjualan terdiri dari serangkaian teknik pemasaran yang dirancang dalam kerangka pemasaran strategis untuk menambah nilai produk atau jasa sehingga tercapai tujuan penjualan dan pemasaran yang spesifik.

Dari pengertian di atas, dapat disimpulkan bahwa promosi penjualan adalah berbagai insentif jangka pendek untuk mendorong konsumen agar segera mencoba atau membeli sebuah produk atau jasa. Promosi penjualan seperti juga periklanan memiliki banyak variasi seperti, hadiah, kupon, voucher, diskon, bonus dan lain-lain. Akan tetapi umumnya, promosi penjualan memberikan manfaat sebagai berikut:

a. Komunikasi, promosi penjualan menarik pemirsanya karena memberikan informasi yang menggiring orang terhadap suatu produk.

b. Insentif, promosi penjualan memberikan sebuah insentif yang menjadi rangsangan bagi pemirsanya.

c. Mengundang, penawaran pada promosi penjualan bersifat segera. Konsumennya diharapkan sesegera mungkin untuk bertindak.

3. Hubungan Masyarakat (Humas) dan Publisitas

Tjiptono (2004) menyatakan bahwa hubungan masyarakat dan publisitas adalah upaya komunikasi menyeluruh dari suatu perusahaan untuk mempengaruhi persepsi, opini, keyakinan, dan sikap berbagai kelompok terhadap perusahaan tersebut. Dalam pengertian ini, yang dimaksud kelompok adalah mereka yang terlibat, mempunyai kepentingan, dan dapat mempengaruhi kemampuan perusahaan dalam mencapai tujuannya. Kelompokkelompok tersebut bisa terdiri atas karyawan dan keluarganya, pemegang saham, pelanggan, khalayak/orang-orang yang tinggal di sekitar organisasi, pemasok, perantara, pemerintah, serta media masa.

Sunarto (2004) menyatakan bahwa hubungan masyarakat adalah kegiatan membangun hubungan baik dengan publik terkait untuk memperoleh dukungan, membangun citra perusahaan yang baik, dan menangani atau menyingkirkan gosip, cerita, dan peristiwa yang dapat merugikan. Sementara itu, Kotler (2001) menyatakan bahwa hubungan masyarakat adalah meliputi berbagai program yang dirancang untuk mempromosikan dan atau melindungi citra perusahaan atau produk individualnya. 
Dari pengertian di atas, dapat disimpulkan bahwa program yang dirancang untuk mempromosikan atau melindungi citra perusahaan atau produk. Kehumasan serta publisitas memang memiliki kelebihan tersendiri dibandingkan bauran komunikasi yang lain, kelebihan tersebut antara lain sebagai berikut:

a. Kredibilitas yang tinggi

b. Sebagai alternatif alat komunikasi

4. Tenaga Penjual (Personal Selling)

Tjiptono (2004) menyatakan bahwa personal selling adalah komunimasi langsung (tatap muka) antara penjual dan calon pembeli/ calon pelanggan untuk memperkenalkan suatu produk kepada calon pelanggan dan membentuk pemahaman pelanggan terhadap produk sehingga mereka kemudian akan mencoba dan membelinya. Sementara itu, Sunarto (2004) menyatakan bahwa personal selling adalah persentase pribadi oleh para wiraniaga perusahaan dalam rangka menyukseskan penuualan dan membangun hubungan dengan pelanggan.

Berdasarkan pengertian di atas, disimpulkan bahwa personal selling adalah interaksi tatap muka dengan salah satu pembeli prospektif dengan tujuan membuat presentasi, menjawab pertanyaan dan mendapatkan pesanan. Kotler (2001) menyatakan bahwa personal selling memiliki kelebihan tersendiri dibandingkan bauran promosi yang lain, yaitu:

a. Konfrontasi langsung dengan calon pembeli

b. Membina hubungan dengan calon pembelinya

c. Respon yang diterima langsung dari konsumen

5. Pemasaran Langsung (Direct Marketing)

Tjiptono (2004) menyatakan bahwa pemasaran langsung adalah sistem pemasaran yang bersifat interaktif, yang memanfaatkan satu atau beberapa media iklan untuk menimbulkan respons yang terukur dan atau transaksi di sembarang lokasi. Dalam pengertian ini, komunikasi promosi ditujukan langsung kepada konsumen individual dengan tujuan agar pesan-pesan tersebut ditanggapi konsumen yang bersangkutan, baik melalui telepon, pos atau dengan dating langsung ke tempat pemasar.

Sunarto (2004) menyatakan bahwa pemasaran langsung adalah komunikasi langsung dengan sejumlah konsumen sasaran untuk memperoleh tanggapan langsung melalui penggunaan surat, telepon, faks, e-mail, dan lainlain untuk berkomunikasi langsung dengan konsumen tertentu atau usaha untuk mendapat tanggapan langsung.

Kotler (2001) menyatakan bahwa ciri-ciri bauran promosi seperti ini adalah nonpublik, karena diarahkan langsung kepada pihak tertentu. juga bersifat segera dan customized secara cepat bisa disampaikan informasinya. Dan ciri lainya adalah interaktif karena pihak konsumen dapat segera merespon pesan yang disampaikan oleh pemasar.

Sementara itu, Belch dan Belch (2007) menyatakan bauran promosi (promotional mix) sebagai alat-alat dasar yang digunakan untuk mencapai tujuan komunikasi organisasi. Secara visualisasi, elemen-elemen bauran promosi dapat dilihat pada Gambar 1 berikut ini. 


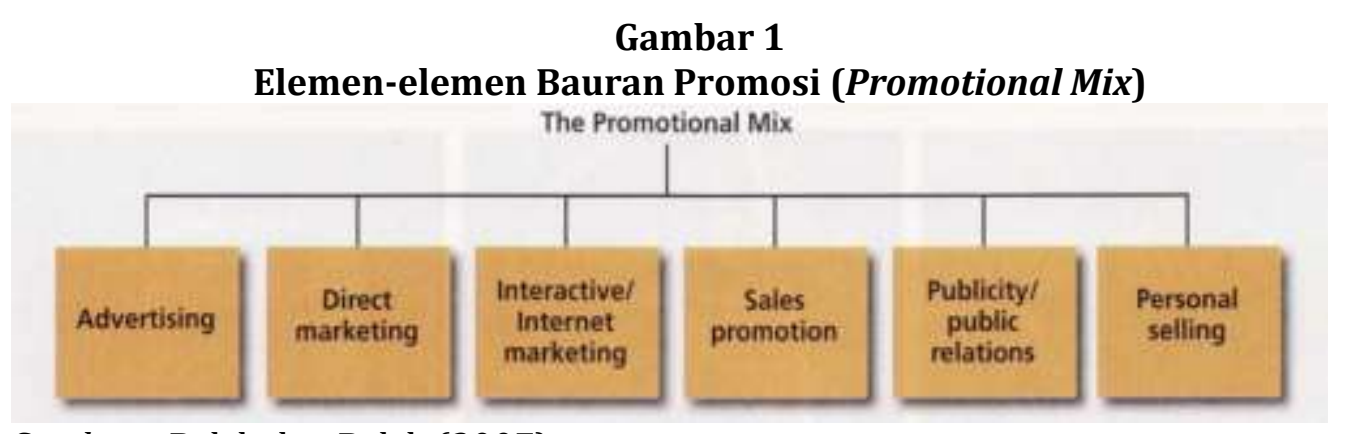

Sumber: Belch dan Belch (2007)

Gambar 1 di atas menunjukkan enam elemen dalam bauran promosi, yaitu : iklan (advertising), pemasaran langsung (direct marketing), pemasaran interaktif atau internet (interactive/internet marketing), promosi penjualan (sales promotion), publisitas dan hubungan masyarakat (publicity/public relation), dan penjualan personal (personal selling). Di era modern saat ini, direct marketing dan interactive/internet marketing merupakan elemen bauran pemasaran utama yang digunakan praktisi pemasaran untuk berkomunikasi dengan target market mereka (Belch dan Belch, 2007).

Iklan (advertising) adalah bentuk dari komunikasi non personal yang tentang organisasi, produk, jasa atau ide oleh sponsor yang mengandung aspek bayar. Aspek bayar dalam definisi ini menggambarkan fakta bahwa pesan iklan harus membeli lokasi tempat dan waktu. Sedangkan komponen non personal berarti iklan mencakup mass media yang memindahkan pesan kepada sekumpulan individual dalam jumlah besar pada saat yang bersamaan. Iklan dapat berupa iklan di TV, radio, majalah, koran dan sebagainya.

Pemasaran langsung (direct marketing) adalah elemen bauran promosi di mana organisasi dapat berkomunikasi secara langsung dengan konsumen untuk menghasilkan tanggapan atau transaksi. Pemasaran langsung berupa direct mail, mail order catalogues, direct selling, telemarketing, e-marketing dan lain sebagainya.

Pemasaran interaktif atau internet (interactive/internet marketing) adalah elemen bauran promosi yang membolehkan arus bolak-balik dari sebuah informasi di mana pengguna dapat berpartisipasi dan memodifikasi bentuk da nisi dari informasi yang mereka terima pada saat itu. Pemasaran interaktif atau internet dapat berupa internet, $C D$ ROMs, kiosks, interactive television, dan lain sebagainya.

Promosi penjualan (sales promotion) adalah aktivitas pemasaran yang menyediakan nilai tambah atau insentif kepada sales force, distributor atau pelanggan utama dan dapat menstimulasi penjualan secara cepat. Promosi penjualan dapat berupa kupon, kontes, harga premi, sampling, sweeptakes, dan lain sebagainya.

Publisitas (publicity) adalah komunikasi non personal mengenai organisasi, produk, jasa atau ide yang tidak secara langsung dibayar atau dijalankan oleh sponsor. Hubungan masyarakat (public relation) adalah fungsi manajemen yang melakukan evaluasi terhadap perilaku produk, mengidentifikasi kebijakan dan prosedur dari seorang individu atau organisasi dengan public interest, dan mengeksekusi aksi program untuk memperoleh pemahaman dan penerimaan dari masyarakat. 
Penjualan personal (personal selling) adalah bentuk komunikasi personal di mana penjual cenderung membimbing atau membujuk pembeli potensial untuk membeli produk, jasa maupun ide dari perusahaan. Penjualan personal dapat berupa telephone sales dan sebagainya.

\section{METODE PENELITIAN}

Penelitian ini merupakan jenis penelitian survey yang bertujuan untuk menggambarkan, menjelaskan dan memaparkan suatu fenomena tertentu yang terjadi di lapangan melalui penyebaran kuesioner dan observasi langsung. Jenis data yang digunakan adalah data primer yang diperoleh melalui penyebaran kuesioner. Populasi dalam penelitian ini adalah seluruh konsumen Matahari Departement Store Bengkulu. Metode penetapan responden digunakan metode accidental sampling. Jumlah sampel yang akan digunakan dalam penelitian ini adalah sebanyak 100 orang responden yang dilakukan dengan penyebaran kuesioner dengan cara diisi langsung di lokasi penelitian. Metode analisis data digunakan analisis deskriptif dengan bantuan distribusi frekuensi, nilai rata-rata dan persentase.

\section{HASIL PENELITIAN DAN PEMBAHASAN}

Promosi merupakan salah satu variabel yang dipakai untuk mempengaruhi pasar bagi suatu produk maupun jasa dari suatu perusahaan. Banyak yang berpendapat bahwa promosi itu sama dengan penjualan, bahkan ada pula yang berpendapat bahwa promosi itu merupakan bagian dari penjualan. Menurut Kotler: "Promosi adalah merupakan informasi atau persuasi satu arah yang dibuat untuk mengarahkan seorang atau organisasi kepada tindakan yang menciptakan pertukaran dalam pemasaran." Sedang menurut Swastha: "Promosi dapat diartikan semua jenis kegiatan pemasaran yang ditujukan untuk mendorong permintaan". Pengertian promosi baik dari Kotler maupun dari Swastha, keduanya tidaklah saling bertentangan. Disatu pihak lebih menitikberatkan kepada penciptaan pertukaran, sedang di pihak yang lain lebih menitikberatkan kepada pendorongan permintaan.

Kegiatan promosi dalam prakteknya menurut Swastha (1995: 278) adalah sebagai alat untuk:

1. Modifikasi tingkah laku;

Orang-orang yang melakukan komunikasi itu mempunyai beberapa alasan, antara lain mencari kesenangan, mencari bantuan, memberikan pertolongan atau intruksi, pengembangan ide dan pendapat. Sedangkan promosi dari segi lain berusaha merubah sikap tingkah laku dan pendapat, serta memperkuat sikap dan tingkah laku yang telah ada. Penjual sebagai sumber selalu berusaha menciptakan kesan yang baik yang ada pada dirinya (lembaganya) untuk mendorong peningkatan pembelian barang dan jasa yang ditawarkan.

2. Pemberitahuan

Kegiatan promosi dapat ditujukan untuk memberitahu pasar yang dituju tentang penawaran hasil produk suatu perusahaan. Promosi yang bersifat informasi ini harus dilakukan sejak tahap-tahap awal dari siklus kehidupan produk. Sebagian konsumen tidak akan membeli suatu produk, apabila mereka belum mengetahui apa bentuk produk tadi dan apa faedahnya produk tadi.

$$
\text { Management Insight, } \mathcal{9}(1): 45-54
$$


Promosi yang bersifat informatif ini sangat penting dilaksanakan, karena akan sangat terkesan membantu konsumen dalam memutuskan untuk membeli atau tidak membeli.

3. Membujuk

Promosi yang bersifat membujuk (persuasi) umumnya kurang disenangi oleh sebagian masyarakat. Namun kenyataannya dewasa ini promosi yang bersifat persuasif ini malah tumbuh dan berkembang, karana hasilnya sangat menguntungkan. Promosi ini terutama ditujukan untuk meningkatkan jumlah pembelian dari suatu produk yang telah mulai memasuki tahap pertumbuhan dalam siklus kehidupannya.

4. Mengingatkan

Promosi yang bersifat mengingatkan dilakukan terutama untuk mempertahankan merk suatu produk agar tetap diminati oleh para konsumen. Promosi macam ini sangat perlu dilakukan apabila produk tadi telah memasuki tahap kedewasaan dalam siklus kehidupannya.

Berdasarkan hasil penelitian, di ketahui bahwa bauran promosi (promotional mix) yang dilakukan oleh Matahari Departement Store Bengkulu telah dapat mengenalkan keberadaan Matahari Departement Store Bengkulu kepada konsumen. Aktivitas periklanan yang dilakukan oleh Matahari Departement Store telah mampu memberikan informasi kepada konsumen terhadap keberadaan Matahari Departement Store. Hal ini juga diperoleh oleh aktivitas bauran promosi lainnya seperi sales promotion, personal selling, dan publisitas telah mampu mempengaruhi perilaku konsumen Matahari Departement Store.

Berdasarkan penjelasan di atas, diketahui bahwa komunikasi pemasaran sangat penting artinya bagi perusahaan. Oleh karena itu, penyampaian sejumlah pesan dan penggunaan visual yang tepat sebagai syarat utama keberhasilan dari sebuah program promosi. Tahapan-tahapan komunikasi dan strategi pesan disusun berdasarkan pencapaian kesadaran atas keberadaan sebuah produk atau jasa (awareness), menumbuhkan sebuah keinginan untuk memiliki atau mendapatkan produk (interest), sampai dengan mempertahankan loyalitas pelanggan. Dalam kajian komunikasi tahapan tersebut dikenal dengan rumusan AIDDA (Attention, Interest, Desire, Decision, and Action). Menurut Soemanagara (2006:30 tujuan komunikasi secara umum adalah untuk mencapai sejumlah perubahan seperti, perubahan pengetahuan (knowledge change), perubahan sikap (attitude change), perubahan perilaku (behaviour change) dan perubahan masyarakat (social change).

Selanjutnya, Kotler (2005:250), mengembangkan delapan langkah dalam program komunikasi dan promosi total yang efektif. Dimana komunikator pemasaran harus : (1) mengidentifikasikan audiensnya; (2) menentukan tujuan komunikasi; (3) merancang isi pesan; (4) memilih saluran komunikasi; (5) menentukan anggaran promosi; (6) membuat keputusan atas bauran pemasaran; (7) mengukur hasil promosi tersebut; dan (8) mengelola dan mengkoordinasi proses komunikasi pemasaran yang terintegrasi. Dari tahapan tersebut, diharapkan bahwa tanggapan terakhir dari audiens adalah berupa pembelian, kepuasan yang tinggi dan cerita dari mulut ke mulut yang baik.

Dari penjelasan di atas, implikasi yang dapat diambil dari penelitian adalah bahwa kegiatan bauran pemasaran (promotional mix) sangat penting dilakukan terutama bagi organisasi ritel. Bahkan ahli pemasaran seperti Kotler menyarankan

$$
\text { Management Insight, } 9 \text { (i): 45 54 }
$$


agar perusahaan harus dapat melaksanakan program bauran pemasaran secara efektif dan total agar dapat menciptakan nilai perusahaan di mata pelanggan. Dengan dikenalnya perusahaan secara baik oleh konsumen, maka kepercayaan konsumen akan terbangun dan pada gilirannya akan membentuk sikap loyalitas konsumen itu sendiri.

\section{KESIMPULAN DAN SARAN}

\section{Kesimpulan}

yakni:

Dari hasil penelitian dan pembahasan dapat ditarik beberapa kesimpulan,

1. Periklanan yang dilakukan oleh Matahari Departement Store telah berjalan baik dan memperoleh perhatian konsumen.

2. Konsumen berpendapat bahwa kegiatan sales promotion yang dilakukan oleh Matahari Departement Store telah berjalan baik dan mampu memberikan dampak positif di hati konsumen.

3. Publisitas yang dilakukan oleh Matahari Departement Store telah mampu menambah kepercayaan konsumen terhadap Matahari Departement Store.

4. Kegiatan personal selling yang dilakukan oleh Matahari Departement Store mampu memberikan informasi yang baik terhadap keberadaan Matahari Departement Store.

5. Direct marketing yang dilakukan oleh Matahari Departement Store telah berjalan baik dan memperoleh perhatian konsumen. Kondisi ini tentu saja dapat meningkatkan kepercayaan di hati konsumen.

\section{Saran}

Berdasarkan hasil peneltian dan kesimpulan, saran yang dapat dipertimbangkan manajemen Matahari Departement Store adalah :

1. Bauran promosi pemasaran lebih ditingkatkan lagi sebagaimana fungsi dari komunikasi pemasaran yakni memodifikasi perilaku konsumen, membujuk, memberitahukan, dan mengingatkan bahwa perusahaan ada.

2. Pelaksanaan bauran promosi pemasaran yang masih belum efektif dilihat dari besarnya nilai rata-rata persepsi responden adalah periklanan. Oleh karena itu, kegiatan periklanan perlu ditingkatkan agar masyarakat luas dapat mengetahui keberadaan Matahari Departement Store, terutama di Kota Bengkulu.

\section{DAFTAR PUSTAKA}

Bitner Mary Jo., 1992. "Evaluating Service Encounters: The Effectcts of Physical Surroundings and Employee Responses." Journal of Marketing. Vol. 54 (April, pp. 69-82.

Blech, George E., dan Blech, Michael, A., 2007. Advertising and Promotion : An Integrated Marketing Communication Perspective, McGraw Hill, New York.

Brannan, Tom, 2004. Integrated Marketing Communications, Alih Bahasa Slamet, Cetakan Pertama, Penerbit PPM, Jakarta.

Cooper D.R., dan Emory, C.W., 1996. Metode Penelitian Survey, Rajawali Prehalindo, Jakarta.

$$
\text { Management Insight, } 9(1): 45-54
$$


Effendy, Onong Uchjana, 2005. Ilmu Komunikasi : Teori dan Praktek, Cetakan Kesembilanbelas, Remadja Rosdakarya, Bandung.

Gitosudarmo, Indriyo, 2000. Manajemen Pemasaran, Cetakan Keenam, BPFE, Yogyakarta.

Keegan, Warren J., 2002. Manajemen Pemasaran Global, Pretice Hall, New Jersey.

Kottler, Philip. 1996. Manajemen Pemasaran: Analisis, Perencanaan, Implementasi, dan Kontrol. Edisi Bahasa Indonesia, jilid 1 dan 2, Jakarta. PT Prenhallindo.

Kotler, Philip, 2001. Manajemen Pemasaran Global, Edisi Bahasa Indonesia, Prenhalindo, Jakarta.

Kottler, Philip and Andreasen, Alan R., 1994. Strategi pemasaran untuk organisasi nirlaba. Edisi ketiga, Yogyakarta.Gajah Mada University Press.

Madura, Jeff, 2001. Pengantar Bisnis, Alih Bahasa Saroyini WS Salib, Edisi Ke 2, Salemba Empat, Jakarta.

Nasrullah, 2004. Pengaruh Bauran Promosi terhadap Keputusan Nasabah untuk Menabung di Bank Rakyat Indonesia Cabang Medan Putri Hijau, Skripsi Jurusan Manajemen FE-USU, tidak dipublikasikan.

Nitisemito, Alex S., 1995. Manajemen Pemasaran, BPFE, Yogyakarta.

Santoso, Singgih. 2000. SPSS : Mengolah Data Statistik Secara Profesional.Jakarta. PT. Gramedia

Sunarto, 2004. Manajemen Pemasaran, UST Press, Yogyakarta.

Sunarto, 2006. Prinsip-prinsip Pemasaran, Edisi Kedua, UST Press, Yogyakarta.

Supriyansyah, Mecky, 2009. Persepsi Konsumen terhadap Bauran Promosi Supermarket Tunjungan Surabaya, Skripsi Jurusan Manajemen FE-UNAIR, Tidak dipublikasikan.

Susanti, Fifi, 2009. Persepsi Konsumen terhadap Kualitas Layanan Pasti Pas Pertamina di Kota Bengkulu (Studi Pada Kendaraan Roda Empat pada SPBU Rawa Makmur Bengkulu), Skripsi Jurusan Manajemen FE-UNIB, Tidak dipublikasikan.

Sutisna, 1999. Perilaku Konsumen, Teori dan Aplikasi. Bandung. Fakultas Ekonomi Universitas Pasundan.

Swastha, Basu, 2002. Manajemen Pemasaran, Andi Offset, Yogyakarta.

Swastha, Basu, dan Irawan, F., 1990. Manajemen Pemasaran Jasa, Andi Offset, Yogyakarta.

Syahjadi, F., 2001. Manajemen Pemasaran Jasa, Rineka Cipta, Jakarta.

Tjiptono, Fandy, 2004. Strategi Pemasaran, Edisi Kedua, Andi Offset, Yogyakarta. 